\title{
Grammatical Errors in the Arabic Essay (Content Analysis Research on the Student of Arabic Language Education Department, Faculty of Languages and Arts, State University of Jakarta)
}

\author{
Ahmad Marzuq \\ Department of Arabic Language Education, Faculty of Languages and Arts \\ State University of Jakarta \\ ahmad.marzuq@unj.ac.id
}

\begin{abstract}
This research is aimed to describing the gramatical errors on the text that committed by the students of Arabic Language and Literature Department, Faculty of Language and Arts, State University of Jakarta. Grammatical errors in this case covering morphological errors and syntactic errors. Data obtained through an Arabic essay writing activities performed by 25 students and then the data were analyzed using the method of error analysis.

The results showed that 25 students essays founded 68 grammatical errors. These grammatical errors consist of 38 syntax errors and 30 morphological errors.

Grammatical errors made by students can be caused by several factors such as the influence of the mother tongue / first, the influence of the second language being studied, as well as the influence of developmental errors.
\end{abstract}

Keywords:gramatical errors, morphological errors, syntactic errors, arabic essay

ABSTRAK

Penelitian ini bertujuan untuk menggambarkan kesalahan gramatikal dalam karangan berbahasa Arab yang dilakukan oleh mahasiswa Program Studi Pendidikan Bahasa Arab Fakultas Bahasa dan Seni Universitas Negeri Jakarta. Kesalahan gramatikal yang dimaksud mencakup kesalahan morfologis dan kesalahan sintaksis. Data diperoleh melalui kegiatan menulis karangan berbahasa Arab yang dilakukan oleh 25 mahasiswa dan kemudian data tersebut dianalisis dengan menggunakan metode analisis kesalahan.

Hasil penelitian menunjukkan bahwa dari 25 karangan mahasiswa ditemukan 68 kesalahan kesalahan gramatikal. Kesalahan gramatikal tersebut terdiri dari kesalahan aspek sintaksis yang mencapai 38 kesalahan dan kesalahan aspek morfologis yang mencapai 30 kesalahan. 
Kesalahan gramatikal yang dilakukan oleh mahasiswa dapat disebabkan oleh beberapa faktor misalnya pengaruh dari bahasa ibu/pertama, pengaruh dari bahasa kedua yang sedang dipelajari, serta pengaruh dari kesalahan perkembangan.

\section{PENDAHULUAN}

Kemampuan menulis dalam pembelajaran bahasa Arab tidak bisa dipisahkan dari ilmu nahwu dan ilmu sharaf. Kedua ilmu ini merupakan dasar yang harus dikuasai seseorang dalam menggunakan bahasa Arab.

Hazarudin mendefinisikan lmu Nahwu dan Ilmu Sharaf sebagai berikut:

$$
\text { قواعد يعرف بها وظيفة كل كلمة داخل الجملة وضبط أواخر الكلمات وكيفية إعرابها }
$$

"Kaidah-kaidah untuk mengetahui kedudukan kata ketika memasuki kalimat dan untuk mengetahui syakal akhir-akhir kata serta tata cara meng-i'rab-nya."

$$
\text { تحويل الأصل الواحد إلى أمثلة مختلفة لمعان مقصودة لا تصل إلا بها }
$$

"Ilmu untuk memindahkan atau mengubah suatu kata asal kepada berbagai bentuk kata, karena menginginkan suatu kata lain yang dimaksud. Dimana proses ini tidak mungkin bisa dicapai kecuali melalui Ilmu Sharaf." ${ }^{\mathrm{i}}$

Seorang pembelajar yang ingin mengungkapkan ide dan gagasannya dalam sebuah tulisan atau karangan tidak bisa menafikan pentingnya kedua ilmu tersebut. Contoh: seorang pembelajar ingin mengungkapkan bahwa kebun yang dilihatnya itu indah. Ia bisa menggunakan kalimat di bawah ini:

Kebun itu indah الحمديقة جميلة المنظر

Kalimat di atas dalam bahasa Arab disebut jumlah ismiyah, predikatnya memakai kata benda. Akan tetapi, bila ingin menggunakan verbal yang predikatnya memakai kata kerja ia harus mengubah kalimat di atas dari kalimat nominal menjadi kalimat verbal, yaitu الحديقة يجمل:harus diubah menjadi kata kerja. Maka kalimat verbalnya adalah جميلة kata منظر هـا menjadi kata جميلة menuntut penguasaan kedua ilmu tersebut. Akan tetapi jika ia hanya memperhatikan kaidah sharaf, maka kata جميلة akan diubah menjadi kata تجمل.

Dari pengamatan awal, mahasiswa kurang menguasai penggunaan kaidah-kaidah tata bahasa Arab (Nahwu-Sharf) dalam kalimat, sehingga diprediksi dapat menyebabkan 
banyaknya kesalahan yang mereka buat pada saat menggunakan bahasa Arab baik secara lisan maupun tulisan. Berkaitan dengan hal tersebut, yang menjadi fokus penelitian ini adalah kesalahan pada tataran gramatikal yang dilakukan mahasiswa dalam karangan berbahasa Arab.

Merujuk pada fokus penelitian di atas, penulis dapat menguraikan menjadi subfokus sebagai berikut:

- Bentuk kesalahan morfologis dilakukan mahasiswa Jurusan Bahasa dan Sastra Arab Universitas Negeri Jakarta dalam karangan berbahasa Arab.

- Bentuk kesalahan sintaksis dilakukan mahasiswa Jurusan Bahasa dan Sastra Arab Universitas Negeri Jakarta dalam karangan berbahasa Arab.

- Faktor-faktor penyebab kesalahan gramatikal dalam karangan berbahasa Arab mahasiswa semester V Jurusan Bahasa dan Sastra Arab Fakultas Bahasa dan Seni Universitas Negeri Jakarta.

\section{PEMBAHASAN}

Menurut Pit S Corder yang dikutip oleh Parera bahwa kesalahan berbahasa adalah suatu bentuk penyimpangan yang sifatnya sistematis, konsisten, dan menjadi ciri khas pembelajar pada tingkat tertentu. ${ }^{\text {ii }}$

Sedangkan Thu'aimah menjelaskan bahwa:

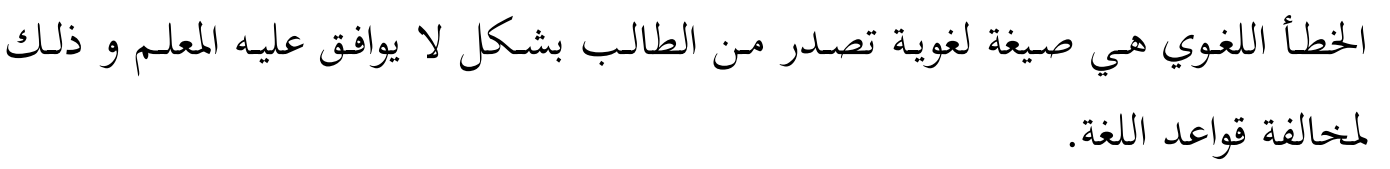

"Kesalahan berbahasa adalah bentuk bahasa pembelajar yang tidak sesuai dengan (arahan) guru, serta menyimpang dari kaidah bahasa."

Sementara itu, analisis kesalahan didefinisikan oleh Tarigan dan Tarigan sebagai berikut:

Suatu prosedur kerja, yang biasa digunakan oleh para peneliti dan guru bahasa, yang meliputi pengumpulan sampel, pengidentifikasian kesalahan yang terdapat dalam sampel, penjelasan kesalahan tersebut, pengklasifikasian kesalahan itu berdasarkan penyebabnya, serta pengevaluasian atau penilai antara keseriusan kesalahan itu. ${ }^{\text {iv }}$

Penelitian ini bertujuan untuk menggambarkan kesalahan gramatikal dalam karangan berbahasa Arab yang dilakukan oleh mahasiswa Jurusan Bahasa dan Sastra Arab Fakultas Bahasa dan Seni Universitas Negeri Jakarta. Kesalahan gramatikal yang dimaksud 
mencakup kesalahan morfologis dan kesalahan sintaksis. Data diperoleh melalui kegiatan menulis karangan berbahasa Arab yang dilakukan oleh 25 mahasiswa dan kemudian data tersebut dianalisis dengan menggunakan metode analisis kesalahan.

Berdasarkan tujuan dan karakteristiknya, penelitian ini menggunakan pendekatan kualitatif dengan metode analisis isi. Seperti yang diungkapkan oleh Bogdan dan Biklen (1982) dalam Sugiyono bahwa penelitian jenis kualitatif lebih bersifat deskriptif, artinya data yang terkumpul dari penelitian ini lebih berbentuk kepada kata-kata atau gambar dibandingkan dengan angka. Penelitian ini juga lebih menekankan kepada analisis data yang menekankan kepada interpretasi makna dibalik data-data yang tersaji. ${ }^{\mathrm{V}}$

Moleongmengatakan bahwa sumber data utama dalam penelitian kualitatif adalah kata-kata dan tindakan, selebihnya adalah data tambahan seperti dokumen, foto, artefak dan statistik. $^{\text {vi }}$

Dalam penelitian kualitatif, peneliti mengembangkan pengetahuan dengan mengumpulkan data berupa data verbal melalui suatu kajian kasus yang intensif serta menarik kesimpulan yang secara induktif. Sementara teknik analisis isi digunakan mengingat dalam penelitian ini data yang tersaji akan berupa hasil karangan yang perlu dianalsis lebih lanjut guna memperoleh makna atau isi yang dapat disimpulkan secara komprehensif. Seperti yang diungkapkan oleh Fraenkel \& Wallen bahwa analisis isi merupakan suatu teknikyangmemungkinkanpenelitiuntuk mempelajari tingkah lakumanusiadalamcara yangtidak langsung, melaluianalisiskomunikasi mereka. ${ }^{\text {vi }}$

Analisis isi dari karangan ini nantinya akan dipergunakan untuk menentukan jenisjenis kesalahan gramatikal yang dilakukan oleh mahasiswa dan dapat dipergunakan sebagai informasi penting untuk mengetahui berbagai jenis kesalahan gramatikal yang muncul. Dalam penelitian ini, peneliti menggunakan pendekatan analisis kesalahan dengan langkahlangkah sebagai berikut: (1) menentukan tujuan penelitian (2) menentukan fokus penelitian, dalam hal ini kesalahan dalam tataran morfologis (3) menentukan prosedur kategorisasi kesalahan (4) melakukan analisis kesalahan dengan menetukan jenis-jenis kesalahan gramatikal yang muncul (5) menarik kesimpulan, berdasarkan acuan teori dan tujuan penelitian.

Data-data penelitian diambil dari karangan berbahasa Arab mahasiswa semester V (ganjil) Jurusan Bahasa dan Sastra Arab Fakultas Bahasa dan Seni Universitas Negeri 
Jakarta. Karangan tersebut dijadikan data penelitian karena data ini dapat diamati secara langsung dalam bentuk tertulis, sehingga memudahkan proses identifikasi dan klasifikasi kesalahan.

Kesalahan-kesalahan yang diperoleh dari 25 naskah karangan yang telah ditulis oleh mahasiswa jurusan Bahasa dan Sastra Arab Universitas Negeri Jakarta pada mata kuliah Ta'bir Tahriry 2, adapun jumlah kalimat yang didalamnya terdapat kesalahankesalahan adalah 68 kalimat.

Tabel I: Tabulasi Kategori Kesalahan

\begin{tabular}{|c|c|c|c|c|c|}
\hline \multicolumn{3}{|c|}{ KATEGORISASI KESALAHAN } & \multicolumn{3}{|c|}{ JUMLAH } \\
\hline \multirow{14}{*}{ KATEGORI } & \multirow{4}{*}{ MORFOLOGIS } & KATA KERJA & 9 & \multirow{4}{*}{30} & \multirow{14}{*}{68} \\
\hline & & KATA BENDA & 3 & & \\
\hline & & HURUF & 10 & & \\
\hline & & BENTUKAN KATA & 8 & & \\
\hline & \multirow{10}{*}{ SINTAKSIS } & STRUKTUR IDHAFAH & 8 & \multirow{10}{*}{38} & \\
\hline & & NA'AT MANUT & 5 & & \\
\hline & & DHOMIR & 2 & & \\
\hline & & JARR MAJRUR & 3 & & \\
\hline & & INNA & 1 & & \\
\hline & & $\boldsymbol{K} \boldsymbol{A} \boldsymbol{A} \boldsymbol{N} \boldsymbol{A}$ & 6 & & \\
\hline & & MASHDARMUAWWAL & 6 & & \\
\hline & & TARKIB & 2 & & \\
\hline & & $M A F^{\prime} U L$ BIH & 3 & & \\
\hline & & $B A D A L$ & 2 & & \\
\hline
\end{tabular}

Setelah dilakukan penelitian terhadap 25 karangan Mahasaiswa Jurusan Bahasa dan Sastra Arab Universitas Negeri Jakarta maka ditemukanlah hasil penelitian sebagai berikut:

1) Jumlah kesalahan keseluruhan adalah 68 kesalahan dari 25 hasil karangan mahasiswa.

2) Adapun 68 kesalahan itu dikategorikan menjadi kesalahan morfologis dan kesalahan sintaksis. Kesalahan morfologis berjumlah 30 (44,11\%) dan kesalahan sintaksis mencapai 38 (55.88\%).

3) Adapun ke-30 kesalahan morfologis terbagi menjadi 4 kategori, yaitu 1. kesalahan kata kerja yang berjumlah 9 (30\%), 2. Kesalahan kata benda dan 
nominal yang berjumlah $3(10 \%)$, 3. Kesalahan huruf yang berjumlah 10 (33.3\%), dan 4. Kesalahan bentukan kata yang berjumlah 8 (26,6\%).

4) Adapun ke-38 kesalahan sintaksis itu terbagi menjadi 10 kategori yaitu: 1. Kesalahan struktur idhafah berjumlah $8(21,05 \%)$, 2. Kesalahan kaidah na'at man'uut berjumlah $5(13,1 \%), 3$ Kesalahan penggunaan kata ganti (dhamir) berjumlah 2 (5,26\%), 4. Kesalahan kaidah jarr majruur berjumlah 3 (7,89\%). 5 . Kesalahan penggunaan inna wa akhwatuha berjumlah 1 (2,63\%), 6. Kesalahan kaidah kaana wa akhwatuha berjumlah 6 (15,7\%), 7. Kesalahan mashdarmuawwal berjumlah $6(15, \%), 8$. Kesalahan struktur kalimat (tarkib) berjumlah 2 (5,26\%), 9. Kesalahan kaidah maf'ul bih berjumlah 3 (7,89\%), dan 10. Kesalahan kaidah badal berjumlah 2 (5,29\%).

\section{PENUTUP}

Berdasarkan hasil analisis terhadap kesalahan-kesalahan morfologis dan sintaksis pada karangan yang telah disusun oleh responden, dapat disimpulkan bahwa mayoritas responden cenderung keliru dalam menerapkan kaidah yang disebabkan oleh alur berfikir dalam bahasa keseharian mereka. Peneliti menemukan juga banyak susunan frase, klausa, atau kalimat dalam bahasa Arab yang merupakan akibat dari penggunaan sistem bahasa pertama yang lebih dahulu dikuasai responden. Proses inilah yang disebut proses interlingual.

Sumber kesalahan lainnya yang juga ditemukan adalah adanya generalisasi, yang berasal dari transfer intralingual, terhadap kaidah-kaidah dalam bahasa arab sebagai bahasa target, yang telah dikuasai responden terlebih dahulu, pada pembentukan frase atau kalimat lain yang relatif baru.

Dengan adanya temuan dalam penelitian ini diharapkan dapat dijadikan bahan pertimbangan dalam meningkatkan kemampuan menulis karangan secara optimal melalui peningkatan penguasaan kosa kata dan ketatabahasaan, baik bahasa pertama siswa maupun bahasa kedua yang menjadi target pembelajarannya. 


\section{REFERENCES}

Fraenkel, Jack R. \& Wallen, Norman E., How to Design and Evaluate Research in Education, New York: McGraw-Hill, 2006

Hazarudin, Bahasa Arab Teoritis (Nahwu Sharaf). Bogor: CV. Bintan Tsurayya, 1994.

Hyland, Ken. Second Language Writing. London: Cambridge University Press, 2003

James, Carl. Errors in Language Learning and Use; Exploring Error Analysis. London: Longman, 1998

Moleong, Lexy J., Metodologi Penelitian Kualitatif. Bandung: Renaya Rosdakarya, 2005

Mulyadi, Kesalahan Sintaktis dalam Tulisan Narasi Bahasa Arab pada Siswa MAN 7 Jakarta. Tesis: Program Pascasarjana Universitas Negeri Jakarta, 2011.

Ni'mah, Fuad, Mulakhkhos Qawa'id Al-Lughah Al-'Arabiyah. Beirut: Daaruts Tsaqafah Al-Islamiyah, tt

Pateda, Mansoer, Analisis Kesalahan Berbahasa, Ende: Nusa Indah, 1989.

Sharples, Mike. How We Write: Writing as Creative Design. New York: Routledge, 1999

Sugiyono. Metode Penelitian Kuantitatif, Kualitatif, dan R\&D. Bandung: Alfabeta, 2007.

Tarigan, Henry Guntur, Menulis sebagai Suatu Keterampilan Berbahasa. Bandung: Angkasa, 1986.

\footnotetext{
'Hazarudin, Bahasa Arab Teoritis (Nahwu Sharaf) (Bogor: CV. Bintan Tsurayya, 1994) h. 2

iijos Daniel Parera, Linguistik Edukasional (Jakarta: Erlangga, 1987), h 50

iii Rusdi Ahmad Thu'aimah, et. al, Ta'lim Al-'Arabiyah Li Ghairi Nathiqina Biha (Mesir: Isesco, 1988), h. 53

${ }^{i v} H e n r y$ Guntur Tarigan dan Djago Tarigan, Pengajaran Analisis Kesalahan Berbahasa (Bandung: Angkasa, 1990), h. 68

${ }^{\vee}$ Sugiyono, Metode Penelitian Kuantitatif, Kualitatif, dan R\&D (Bandung: Alfabeta, 2007)., h. 13-14

vi Lexy J. Moleong, Metodologi Penelitian Kualitatif, (Bandung: Renaya Rosdakarya, 2005), h. 157

vii Jack R. Fraenkel \& Norman E. Wallen, How to Design and Evaluate Research in Education, (New York:

McGraw-Hill, 2006), p. 483
} 